\title{
Importance and Potentiality of Underutilized Lakoocha (Artocarpus lakoocha Roxb) Fruit of Tripura
}

\author{
S. Islam ${ }^{1}$, M.A. Hasan ${ }^{2}$, Sonam Ongmu Bhutia ${ }^{2 *}$, Tamanna Perween ${ }^{2}$ and P.S. Munsi ${ }^{3}$ \\ ${ }^{1}$ Department of Horticulture, Institute of Agricultural Science, University of Calcutta, \\ Ballygunge Circular Road, Kolkata-19, India \\ ${ }^{2}$ Department of Fruits and Orchard Management, Faculty of Horticulture, Bidhan Chandra \\ Krishi Viswavidyalaya, West Bengal-741252, India \\ ${ }^{3}$ Department of Horticulture, Palli Siksha Bhavana (Institute of Agriculture), Visva-Bharati, \\ Sriniketan, Birbhum, West Bengal- 731236, India \\ *Corresponding author
}

\section{A B S T R A C T}

\begin{tabular}{|l|}
\hline K e y w o r d s \\
$\begin{array}{l}\text { Lakoocha fruit, } \\
\text { Biodiversity, } \\
\text { Underutilized, Physico- } \\
\text { chemical, Nutritional } \\
\text { food security }\end{array}$ \\
\hline Article Info \\
\hline $\begin{array}{l}\text { Accepted: } \\
\text { 20 August } 2018 \\
\text { Available Online: } \\
\text { 10 September } 2018\end{array}$ \\
\hline
\end{tabular}

The Lakoocha (Artocarpus lakoocha Roxb) is less known minor fruit and it is native to India especially humid sub-Himalayan region. This fruit is also called as Monkey jack in India, Cham or Dewaphol in Tripura and Barhal fruit in Bengal. These fruit are consumed in different form by various ethnic groups. Tripura have many underutilized fruits that are popular among people due to their diversified use and have remained wild or semi domesticated due to lack of research support. Lakoocha fruit plays a significant role as food and nutritional security of rural and urban population of the state. Lakoocha were analyzed for their morpho, physico-chemical properties in terms of plant, fruit characters, edible portion, moisture, juice, TSS, titratable acidity and ascorbic acid (Vitamin-C). There is a need of further research on the evaluation of physico-chemical, nutritive values and medicinal uses particularly the antioxidant properties of Lakoocha fruits. There is also a need for survey of growing areas, selection of elite types and their documentation and standardization of cultivation practices for popularization of Lakoocha fruit throughout the country and their potentiality for commercial exploration can be exploited.

\section{Introduction}

The Lakoocha (Artocarpus lakoocha Roxb) is underutilized fruit, belong to the family of Moraceae and it is native place to India or India to Malacca (Pareek et al., 1993) and in Bengal according to Hayes (1970). The tree grows as wild in tropical climate but it also grows in the sub-tropics where humidity is high in different localities especially Tripura.
In India, this fruit is known in different names (like Dahu, Barhal, Chama, Dewa, Jeuta, Deheo, Lahu, Lovi, Irappala, Lakuchamu, Kaunagona, Wotomba, Kammaregu, Votehuli, Daua, Deophal, Lakuch etc.) in different places as Monkey jack, especially in Tripura as Chama or Dewaphol and Barhal fruit in Bengal (Mazumdar, 2004). It plays a significant role as food and nutritional security of rural, tribal and urban population of the 
state as it has a unique food value and medicinal properties. According to analysis report of Gopalan et al., (1993), the fruits contain $89.6 \%$ moisture, $1.6 \%$ protein, $1.2 \%$ fat, $1.1 \%$ mineral matter, $2.8 \%$ fibre, $13.9 \%$ carbohydrate, $0.067 \%$ calcium and $0.025 \%$ phosphorus. Similar observation was also reported by Jahan et al., (2011). The raw fruit and male flower spike is acidic and astringent at early stage. Several fresh and processed products can be prepared from it like pickle, RTS drink, nectar, squash, jelly etc. It is also used for cattle feed, timber and has medicine properties (Joshee et al., 2002). However, the plant population of lakoocha fruit tree is gradually declining due to intensive exploitation for fuel, timber and other uses coupled with poor seed viability (Napier and Robins, 1989). Meager information is available about it and till date there are no established cultivars in India, hence there is an urgent need in systematic survey for selection of elite types and documentation and standardization of cultural practices for popularity in India as well as throughout the world and their potentiality for commercial exploration. Looking at the importance of this fruit, the investigation was carried out in the district of West Tripura to collect information about lakoocha with the help of villagers and observed the variability within the plant or fruit in respect of morpho, physico-chemical properties in existing germplasms in order to prevent the decline of elite types by conservation and ensure its potentiality for commercial cultivation with standard method of propagation.

\section{Materials and Methods}

The systematic survey, collection and characterization of six different types were evaluated by frequent visits in different growing areas in Tripura and enquiries were made from the villagers and officials of state departments of horticulture and agriculture of the study areas during 2015-2017 to identify the superior types (Table 1) in Tripura. The trees were characterized in-situ for characterization (tree height, tree canopy, leaf length, leaf width, petiole length and yield, etc). The selected fruits were harvested at mature unripe stage. The fruits at edible ripe stage were selected for physico-chemical analysis in order to study the variability attributes. The physico-chemical analysis was carried out in Department of Horticulture, University of Calcutta, Kolkata and Department of Fruits \& Orchard Management, Bidhan Chandra Krishi Viswavidyalaya, Nadia. The minimum fruit sample size in each type was three and each tree was considered as replication. Total weight of the fruit was recorded in grams with the help of digital weight measuring tools. The selected fruit was cut with the help of cutting knife and different parts of fruits were recorded separately. Pulp mass was recorded in grams after removing seeds from the bulbs. Pulp colour was observed and recorded. Total mass of the bulbs of each fruit was divided by total number of bulb in grams. The total soluble solid (TSS) was determined by pocket digital refractometer. The chemical parameters like titratable acidity and ascorbic acid were estimated by the using standard method of AOAC (1984). The fruit quality parameters viz. TSS ('brix), acidity (\%), and ascorbic acid $(\%)$ were statistically analysis.

\section{Results and Discussion}

The objective of the investigation was to find out the superior elite desirable genotypes selection from backyards/kitchen garden of homestead orchard of fruit trees in which scatterly found mostly single plant grows in undulate areas of wastelands in Tripura and to observe wide variability among the genotypes with regards to morpho, physico-chemical characteristics. These desirable elite types were selected on the basis of physico-chemical 
parameters and organoleptic taste for table purpose, conservation and bring to popularization. The qualitative and quantitative data on morpho, physicochemical characters of lakoocha types has been presented in Table 1, 2 and 3.

There was a wide variation observed in lakoocha trees, leaves and fruits among the genotypes. The tree were medium in size (5$7 \mathrm{~m}$ ), deciduous with dark colour bark, large leathery leaves $(16-24 \mathrm{~cm}$ long and 10 to $16 \mathrm{~cm}$ wide), green, broadly ovate to oblong, base rounded, unequal and inwards. Male and female flowers were borne separately on the same plant. The flower colour was orange to yellow in early stage and gradually changing in to reddish. In the six germplasm, the flowering started in the month of December to February and fruiting in May to July. A similar flowering and fruiting season has also been reported earlier by Sankaran et al., (2006). The fruiting seasons varied among the all types. The fruits were irregular in shape, ranging between 5 to $9 \mathrm{~cm}$ long and 3 to $6 \mathrm{~cm}$ wide, greenish at early to mature stage and velvety dull yellow during ripe stage. The fruit qualities of all the types were excellent. The thickness of pulp varied from thin to thick with low to high fiber content. Pulp tastes were intermediate to sweet sour and pulp flavour was weak to strong in all types when it was eaten as fresh (organoleptic taste). The juiciness of pulp was firm to juicy. The moisture content in fruits ranged from 79.8 to $87.11 \%$. The pulp colour of all types was found to be yellow to deep yellow (orange).

A wide range of variation was recorded in fruit length, fruit diameter, fruit weight, peel, pulp, core weight, seed length, seed breadth, seed weight, number of seeds, number of fruits and yield per trees (Table 2). The fruit weight of these types were ranged from 150 gram (Type-2) to 350 gram (Type-3) and fruit yield per tree was lowest in Type-2 $(58.5 \mathrm{~kg})$ and highest in Type-3 $(98 \mathrm{~kg})$. The numbers of fruits per tree were 250 to 390 and pulp weight was highest in Type-3 (216.36 gram) followed by Type-5 (189.23 gram) and lowest in Type-2 (102.33 gram). Peel weight was lowest in Type-2 (17.67 gram) while it was maximum in Type-3 (35.00 gram). Pulp/peel ratio was highest in Type-5 (8.23 gram) while it was lowest in Type-4 (5.66 gram). Core weight among all the types was varied from 16.47 to 89.01 gram. Seed length and breadth was maximum in Type-6 $(1.20 \mathrm{~cm}$ and 1.18 $\mathrm{cm}$ respectively) while minimum was recorded in Type-2 $(0.86 \mathrm{~cm}$ and $0.89 \mathrm{~cm}$ respectively). Numbers of seeds and weight of seeds per fruit were found to be minimum in Type-2 (5 and 3.53 gram respectively) while maximum was observed in Type-3 (14 and 9.66 gram respectively), which were fleshy with thin seed coat among the genotypes. Few research workers have all reported the variability in respect of tree, leaves, fruit shape, size, colour, fruit and seed weight, number of seeds per fruit, yield, TSS and acidity (Majumdar, 2004; Shukla et al., 2008; Dwivedi et al., 2011 and Islam et al., 2011). Also a wide range of bio-chemical variation has been depicted in lakoocha fruits in Table 3. TSS ranged from 12.89 brix (Type-5) to $20.20^{\circ}$ brix (Type-6) and titratable acidity was found minimum in Type-6 (0.87 \%) while maximum titratable acidity was found in Type-5 (2.66 \%). The TSS: acid ratio was varied from 4.85 to 23.22 among the genotypes (Table 3). In respect of biochemical parameters, TSS:acid ratio is economically important as it determines the taste and acceptability of jackfruit (Islam et al., 2011). The maximum amount of ascorbic acid (vitamin-C) was found in Type-4 (182.04 $\mathrm{mg} / 100 \mathrm{~g}$ of pulp) while minimum in Type-5 (168.44 mg/100g of pulp). In the present study of ascorbic acid content in monkey jack, it was found to be higher than reports of Jahan et al., (2011) who recorded ascorbic acid content of $171.07 \mathrm{mg}$ per $100 \mathrm{~g}$ of fruit pulps. 
Table.1 Morpho-physical characteristics of monkey jack trees in Tripura

\begin{tabular}{|c|c|c|c|c|c|c|c|c|c|c|c|}
\hline Genotype & $\begin{array}{c}\text { Tree } \\
\text { height } \\
\text { (m) }\end{array}$ & $\begin{array}{c}\text { Tree } \\
\text { canopy } \\
\text { (m) }\end{array}$ & $\begin{array}{c}\text { Tree } \\
\text { surface }\end{array}$ & $\begin{array}{c}\text { Tree } \\
\text { bark } \\
\text { colour }\end{array}$ & $\begin{array}{l}\text { Leaf } \\
\text { length } \\
\text { (cm) }\end{array}$ & $\begin{array}{l}\text { Leaf } \\
\text { width } \\
\text { (cm) }\end{array}$ & $\begin{array}{c}\text { Petiole } \\
\text { length } \\
\text { (cm) }\end{array}$ & $\begin{array}{l}\text { Leaf } \\
\text { shape }\end{array}$ & $\begin{array}{l}\text { Leaf } \\
\text { colour }\end{array}$ & $\begin{array}{c}\text { Flowering } \\
\text { season }\end{array}$ & $\begin{array}{l}\text { Fruiting } \\
\text { season }\end{array}$ \\
\hline Туре-1 & 6.4 & 4.4 & Smooth & $\begin{array}{c}\text { Dark } \\
\text { brown }\end{array}$ & 20.2 & 13.3 & 2.7 & $\begin{array}{c}\text { Broadly } \\
\text { ovate }\end{array}$ & Green & December & June \\
\hline Туре-2 & 6.6 & 5.2 & Rough & $\begin{array}{l}\text { Light } \\
\text { brown }\end{array}$ & 24.0 & 15.5 & 2.4 & $\begin{array}{c}\text { Broadly } \\
\text { ovate to } \\
\text { oblong }\end{array}$ & $\begin{array}{l}\text { Light } \\
\text { green }\end{array}$ & December & May \\
\hline Туре-3 & 6.4 & 6.3 & Smooth & $\begin{array}{l}\text { Light } \\
\text { brown }\end{array}$ & 19.0 & 12.3 & 3.2 & $\begin{array}{c}\text { Broadly } \\
\text { ovate }\end{array}$ & $\begin{array}{l}\text { Light } \\
\text { green }\end{array}$ & January & May \\
\hline Туре-4 & 6.9 & 5.5 & Smooth & $\begin{array}{l}\text { Light } \\
\text { brown }\end{array}$ & 23.4 & 14.1 & 2.2 & $\begin{array}{c}\text { Broadly } \\
\text { ovate }\end{array}$ & $\begin{array}{c}\text { Dark } \\
\text { green }\end{array}$ & January & June \\
\hline Туре-5 & 5.2 & 4.2 & Smooth & $\begin{array}{l}\text { Light } \\
\text { brown }\end{array}$ & 16.3 & 10.6 & 2.8 & $\begin{array}{c}\text { Broadly } \\
\text { ovate to } \\
\text { oblong }\end{array}$ & Green & December & July \\
\hline Туре-6 & 6.8 & 6.0 & Rough & $\begin{array}{c}\text { Dark } \\
\text { brown }\end{array}$ & 18.6 & 13.8 & 2.9 & $\begin{array}{c}\text { Broadly } \\
\text { ovate to } \\
\text { oblong }\end{array}$ & $\begin{array}{l}\text { Dark } \\
\text { green }\end{array}$ & December & July \\
\hline Mean & 6.38 & 5.26 & & & 20.25 & 13.26 & 2.70 & & & & \\
\hline Std. Dev. & 0.6145 & 0.843 & & & 2.962 & 1.674 & 0.357 & & & & \\
\hline Std. Err. & 0.250 & 0.344 & & & 1.209 & 0.683 & 0.146 & & & & \\
\hline
\end{tabular}


Table.2 Morpho - physical characteristics of collected lakoocha fruits in Tripura

\begin{tabular}{|c|c|c|c|c|c|c|c|c|c|c|c|c|c|c|c|c|c|c|}
\hline \multirow[b]{2}{*}{ 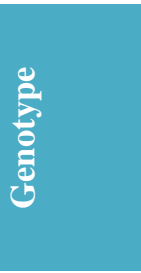 } & \multirow[b]{2}{*}{ 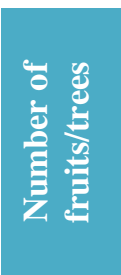 } & \multicolumn{5}{|c|}{ Fruit } & \multirow[b]{2}{*}{ 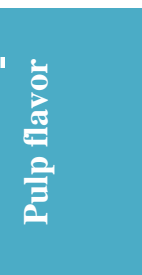 } & \multirow[b]{2}{*}{$\begin{array}{l}\frac{0}{5} \\
\frac{5}{5} \\
\frac{\varrho}{E} \\
\Xi\end{array}$} & \multirow[b]{2}{*}{$\begin{array}{l}\text { 音 } \\
\frac{8}{8} \\
\frac{0}{3} \\
\text { ᄅ }\end{array}$} & \multirow{2}{*}{ 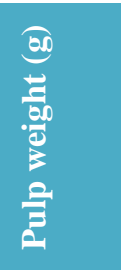 } & \multirow{2}{*}{ 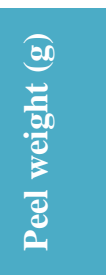 } & \multirow{2}{*}{ 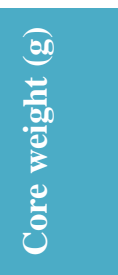 } & \multirow{2}{*}{ क्ष } & \multirow[b]{2}{*}{ 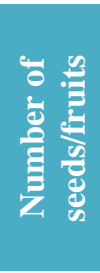 } & \multicolumn{2}{|c|}{ Seed } & \multirow{2}{*}{ 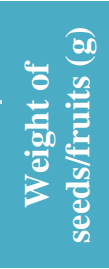 } & \multirow{2}{*}{ 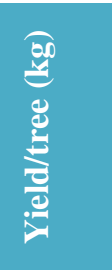 } \\
\hline & & 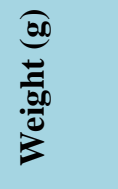 & 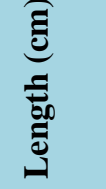 & 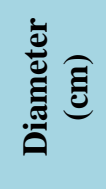 & ๘ँ & $\frac{3}{3}$ & & & & & & & & & 䒿 & 胥 & & \\
\hline Type-1 & 350 & 180.0 & 6.2 & 5.0 & Irregular & $\begin{array}{l}\text { Greenish } \\
\text { to yellow }\end{array}$ & Medium & Sweet sour & Yellow & 134.00 & 23.33 & 16.47 & 5.74 & 8.77 & 1.00 & 0.99 & 6.20 & 63.0 \\
\hline Tyрe-2 & 390 & 150.0 & 8.1 & 4.2 & Irregular & Yellow & Strong & Sweet sour & Yellow & 102.33 & 17.67 & 26.47 & 5.79 & 5.00 & 0.86 & 0.89 & 3.53 & 58.5 \\
\hline Type-3 & 280 & 350.0 & 5.2 & 6.2 & Irregular & $\begin{array}{c}\text { Dull } \\
\text { yellow }\end{array}$ & Medium & Intermediate sour & $\begin{array}{c}\text { Deep } \\
\text { yellow }\end{array}$ & 216.36 & 35.00 & 89.01 & 6.18 & 13.67 & 0.87 & 0.98 & 9.66 & 98.0 \\
\hline Type-4 & 250 & 250.0 & 6.3 & 4.3 & Irregular & $\begin{array}{l}\text { Greenish } \\
\text { to yellow }\end{array}$ & Mild & Sweet sour & $\begin{array}{c}\text { Deep } \\
\text { yellow }\end{array}$ & 145.33 & 25.67 & 72.41 & 5.66 & 9.33 & 0.98 & 1.00 & 6.59 & 62.5 \\
\hline Type-5 & 290 & 300.0 & 8.2 & 5.5 & Irregular & $\begin{array}{c}\text { Dull } \\
\text { yellow }\end{array}$ & Strong & Intermediate sour & Orange & 189.23 & 23.00 & 80.14 & 8.23 & 10.65 & 1.02 & 1.00 & 7.53 & 87.0 \\
\hline Type-6 & 370 & 220.0 & 5.4 & 3.3 & Irregular & Yellow & Strong & Intermediate sour & Yellow & 119.18 & 18.33 & 77.16 & 6.51 & 7.33 & 1.20 & 1.18 & 5.18 & 81.4 \\
\hline Mean & 321.66 & 241.66 & 6.56 & 4.75 & & & & & & 151.07 & 23.83 & 60.27 & 6.35 & 9.12 & 0.98 & 1.00 & 6.44 & 75.06 \\
\hline Std. Dev. & 56.005 & 74.677 & 1.300 & 1.032 & & & & & & 43.441 & 6.281 & 64.070 & 0.974 & 2.945 & 0.123 & 0.094 & 2.082 & 16.040 \\
\hline Std. Err. & 22.864 & 30.486 & 0.530 & 0.421 & & & & & & 17.734 & 2.564 & 26.156 & 0.397 & 1.202 & 0.05 & 0.038 & 0.85 & 6.548 \\
\hline
\end{tabular}

Table.3 Bio-chemical parameters of collected lakoocha fruits in Tripura

\begin{tabular}{|c|c|c|c|c|c|}
\hline Genotype & Moisture (\%) & TSS (brix) & Titratable acidity (\%) & TSS/Acid ratio & Ascorbic acid (mg/100g) \\
\hline Type-1 & 83.56 & 16.44 & 1.22 & 13.48 & 170.20 \\
\hline Type-2 & 84.67 & 15.33 & 1.11 & 13.81 & 175.70 \\
\hline Type-3 & 81.78 & 18.22 & 0.99 & 18.40 & 170.12 \\
\hline Type-4 & 85.64 & 14.36 & 1.67 & 8.60 & 182.04 \\
\hline Type-5 & 87.11 & 12.89 & 2.66 & 4.85 & 168.44 \\
\hline Type-6 & 79.8 & 20.20 & 0.87 & 23.22 & 172.10 \\
\hline Mean & 83.76 & 16.24 & 1.42 & 13.73 & 173.10 \\
\hline Std. Dev. & 2.654 & 2.423 & 0.666 & 6.589 & 5.033 \\
\hline Std. Err. & 1.083 & 0.915 & 0.272 & 2.69 & 2.054 \\
\hline
\end{tabular}


The result of the present study indicates that in Tripura the lakoocha fruit tree is being grown in the homestead orchard garden or is found growing singly in a scatterly manner in undulated areas of wastelands.

The enormous variability among 6 (six) genotypes with respect to fruit quality and quantity parameters was observed. Among all the germplasms, Type- 3 was found to be the superior as it recorded the best fruit qualitative and quantitative characters and is well suited as table purpose, while the other types can be used for both processing and table purposes.

The selected elite types are subjected to improvement by adapting standard method of breeding programme for multiplication, free distribution among the farmers or growers in order to popularize this underutilized fruit.

\section{References}

A.O.A.C. 1984. Official Method of Analysis (14 ${ }^{\text {th }}$ Edn.), Association of Official Analytical Chemists, Washington D.C, USA. pp. 160-186.

Gopalan, C., Rama Sastri B.V., Bala Subramanian, S.C. 1993. Nutritive Value of Indian Foods. National Institute of Nutrition, ICMR, Hyderabad- 500007.

Hayes, W.B. 1970. Fruit Growing in India. Kitabistan, Allahabad, India.

Islam, S., Datta, M., Sankaran, M., Prakash, J., Das, S.P., Biswas, S., Singh, N.P., Ngachan, S.V. 2011. Underutilized Pomological Crops of Tripura-An Unexplored Potential. In: Book of Abst. $1^{\text {st }}$ Tripura Sci. Cong. 8-12 Sept. 2011. Agartala, Tripura, India.

Islam, S., Hasan, A., Munsi, P.S., Datta. M. 2011. Survey, Conservation and Multiplication of Baromasia Jackfruit (Artocarpus heterophyllus Lam) in
Tripura for Commercial Exploitation. In: Book of Abst. $1^{\text {st }}$ Tripura Sci. Cong. 8-12 Sept. 2011. Agartala, Tripura, India.

Jahan, S., Ghosh, T., Begum, M., Saha, B.K. 2011. Nutritional Profile of Some Tropical Fruits in Bangladesh: Specially Anti-Oxidant Vitamins and Minerals. Bangladesh J. Medical Sci. Vol.10:2.

Joker, D., Adhikari, B. 2003. Artocarpus lakoocha Roxb. In: Seed leaflet. No.73. DTDC. $w w w . a f s c . d k$.

Joshee, N., Bastola, D.R., Agarwal, V.P., Yadav, A.K. 2002. Lakoocha (Artocarpus lakoocha Roxb): A Multipurpose Tree of Warm Climate. In: Trends in New Crops and New Uses, Edn. by Janick, J. and Whipkey, A. ASHS Press, Alexandria, VA, pp. 405406.

Majumdar, B.C. 2004. Minor Fruit Crops of India Tropical and Sub-tropical. Daya Publishing House, New Delhi. pp. 2526.

Napier, I., Robins, M. 1989. Forest seeds and Nursery practice in Nepal. pp. 94-95.

Pareek, O.P., Sharma, S. 1993. Genetic Resources of Under-Exploited Fruits. In: Advances in Horticulture, Vol-I Fruit Crops, Part 1, Edn. by K.L Chadha and O.P Pareek. Malhotra Publishing House, New Delhi-110064.

Pater, K.V.2007. Underutilized Fruit Crops. In: Book of Underutilized and Underexploited Horticultural Crops. Kerela Agri. Univ. Trissur-680656, Vol-2:27.

Sankaran, M., Prakash, J., Singh, N.P., Suklabaidya, A. 2006. Wild Edible Fruits of Tripura. Natural Product Radiance, 5 (4):302-305.

Shukla, S., Ali, A., Pandey, D., Pandey, G. 2008. Physico-Chemical Characterization of Barhal (A. Lakoocha) Genotypes Collected from Central Uttar Pradesh. Souvenir: 


\section{National Seminar on Sustainable Perspective, Priorities and Horticultural Research in India, Preparedness. 14-15 April, pp.20.}

\section{How to cite this article:}

Islam, S., M.A. Hasan, Sonam Ongmu Bhutia, Tamanna Perween and Munsi, P.S. 2018. Importance and Potentiality of Underutilized Lakoocha (Artocarpus lakoocha Roxb) Fruit of Tripura. Int.J.Curr.Microbiol.App.Sci. 7(09): 3132-3138.

doi: https://doi.org/10.20546/ijcmas.2018.709.390 